\title{
Section 174 of the Criminal Procedure Act: Is it time for its abolition?
}

\author{
Managay Reddy \\ School of Law, University of Kwazulu-Natal
}

\section{OPSOMMING}

\section{Artikel 174 prosedure van die Strafproseswet}

\begin{abstract}
Alhoewel nuttig, staan artikel 174 prosedure van die Strafproseswet die gevaar om misbruik te word as 'n aanspreeklikheidsvermydingsmeganisme, ten koste van die wyer belang van geregtigheid. Dit kan geargumenteer word dat daar reeds gewysdes is waarin hierdie gevaar verwerklik is: Die hoë-profiel saak $S v$ Dewani, waarin die artikel 174 prosedure suksesvol ingespan om die drie beskuldigdes se ontslag te bewerkstellig, kan dien as voorbeeld. Hierdie artikel spoor die oorsprong van artikel 174 van die Strafproseswet in Suid-Afrikaanse reg na, en toon aan dat die omstandighede wat in die verlede aanleiding gegee het tot die skep van artikel 174 , nie meer teenwoordig is nie. In die lig van hierdie afwesigheid van geskiedkundige regverdigingsfaktore, en bedag op die gebrek aan sekerheid in die regterlike uitoefening van die ontslag-toets, assesseer hierdie artikel die nut, nodigheid, en gepastheid van die artikel 174 prosedure in huidige Suid-Afrikaanse reg. Ten einde emuleer-waardige beste praktyk te vind, word Kanadese and Engelse benaderings tot die ontslag-prosedure onder die loep geneem.
\end{abstract}

\section{Introduction}

Amongst the litany of fair trial rights that exist in South African criminal and procedural law is the presumption of innocence. This right provides that an accused person is presumed to be innocent until proven guilty. The presumption of innocence obliges the state to show guilt beyond a reasonable doubt in order for an accused to be convicted. Therefore, for a conviction to ensue the state is required, at the close of its case, to have rebutted the presumption of innocence by leading sufficient evidence against the accused, upon which a reasonable person could convict.

A failure by the state to mount sufficient evidence for a conviction at the close of its case, gifts the accused the opportunity to escape having to be put on their defence. This gift takes the form of a procedural device in the Criminal Procedure Act, ${ }^{1}$ namely section 174 , which provides:

"If, at the close of the case for the prosecution at any trial, the court is of the opinion that there is no evidence that the accused committed the offence referred to in the charge or any offence of which he may be convicted on the charge, it may return a verdict of not guilty."

If the application of the provisions of section 174 favour the accused they are discharged from prosecution without having to testify - but with the

1 Act 51 of 1977 (hereafter the CPA).

How to cite: Reddy 'Section 174 of the Criminal Procedure Act: Is it time for its abolition? 
same advantages as would have accrued if the trial had run its course and if they had been acquitted.

The article traces the origin and application of section 174 of the Criminal Procedure Act in South African law and shows that the circumstances which warranted the adoption of the section 174 procedure are no longer present. Therefore, in light of the absence of the historical factors justifying the procedure, and mindful of the lack of certainty in the judicial application of the test for a discharge, an assessment is conducted of the utility, need and appropriateness of the procedure in current South African law. The Canadian and English approaches to the procedure are scrutinised briefly, with a view to understanding its application in these jurisdictions, and for guidance on best practices worthy of emulation.

The section 174 procedure, although useful, risks morphing into a process to avoid accountability - so compromising the broader interests of justice. Arguably, there are cases where this risk has materialised: In $S$ $v$ Dewani, ${ }^{2}$ it was successfully employed by a high-profile defence team to see the three accused in a murder trial acquitted. The judgment and order of the court drew harsh media and public criticism, which, it is submitted, may not have been wholly unjustified from a legal perspective. The argument may be warranted that the court in Dewani deviated so drastically from the parameters of the test for a discharge in terms of section 174 of the CPA, that a miscarriage of justice occurred in that an accused person against whom a prima facie case had been made was acquitted without having been put his defence.

The decision in Dewani has further lent credence to the perception that justice through the courts exists only for the wealthy. It is commonplace that the public has an interest in the proper trial of accused persons. Acknowledgement of this is evident in South African legislation, jurisprudence and policy which recognise the interests of victims at the trial stage. Legal decision-making and conclusions which compromise these interests pose problems in the context of a system aimed at serving such interests. This is particularly so when these decisions and conclusions are founded on an over-zealous approach to the application of existing principles.

At the very least, therefore, there is a need to clarify the parameters of the test and the judicial inquiry that needs to occur when a section 174 application is made. Furthermore, although section 174 remains a valuable tool in the fair trial rights' arsenal, South African courts seem to have misconstrued what is required of the state when it closes its case, and of the judges when they assess whether evidence exists at this stage. Applications of the test inherent in section 174 have been inconsistent and have resulted in the exploitation of legal loopholes which then triumph over the goals of the criminal justice system. 


\section{Development of the Section 174 Procedure}

The discharge procedure was absent in South African criminal law at the turn of the twentieth century, but in 1917 it was imported into South African law from nineteenth century English law. ${ }^{3}$ In its original form in civil courts, the plaintiff was required only to show that there was "a scintilla of evidence" against the defendant to avoid his or her claim being dismissed. ${ }^{4}$ The standard of proof was subsequently raised to evidence which would be considered sufficient by a reasonable person for a conviction. ${ }^{5}$ A failure to meet the standard resulted in the defendant being granted absolution from the instance.

In English criminal law, following a successful submission by the defence that there was "no case to answer", the court would return a verdict of not guilty, without requiring the defence to advance its case. ${ }^{6}$ In 1981, the English Criminal Court of Appeal made it clear that the question to be asked by a trial court when faced with a submission of no case to answer, is whether evidence exists on which a jury, directed properly, could properly convict. Naturally, as it is rare for the state to present no evidence at all, such an interpretation might render the procedure empty of usefulness in most cases. The Criminal Court of Appeal, therefore, clarified by stating that: where the judge concludes that the Crown's evidence is such that a jury could not make a conviction based on evidence at its highest, it is the judge's duty on a submission being made to stop the case, but where Crown evidence depends on an assessment of the witness's reliability or on matters within the province of a jury and where one possible view of the facts suggests evidence on which a jury could make a conviction then the judge should allow the matter to go to trial by jury, and with borderline cases left to the discretion of the judge. ${ }^{7}$

The discharge procedure evidently arose out of the need to protect the integrity of the judicial process when it was being administered by laypersons. As a result, the test for discharge arose out of the need to protect the role of juries as triers of fact. This was set out in a speech from the House of Lords in a civil action:

"The Judge has a certain duty to discharge and the jurors have another and a different duty. The Judge has to say whether any facts have been established by evidence from which negligence may be reasonably inferred; those jurors

have to say whether from those facts submitted to them, negligence ought to

$3 \quad R v$ Smith 1912 AD 386; s 221(3) of Act 31 of 1917. When the Criminal Procedure Act 56 of 1955 was enacted, the same procedure was incorporated under s 157(3). It now finds expression in s 174 of the Criminal Procedure Act 51 of 1977.

$4 \quad$ Ferrand v Bingley Township District Local Board (8 T.L.R) 71.

5 Ibid.

$6 \quad R v$ Fardully 1914 AD 186. Even at this stage, the judicial comment as to the standard was that the evidence must be so weak that it would be wholly unreasonable for the jury to convict.

$7 \quad R v$ Galbraith [1981] 2 All ER 1060, 1061. 
be inferred. It is, in my opinion, of the greatest importance in the administration of justice that these separate functions should be maintained, and should be maintained distinct." 8

For this reason, at the close of the Crown's case, judges in England were authorised to decide whether evidence existed upon which a conviction could be made, based on a clinical legal inquiry: Was there evidence led which, if accepted, would satisfy the elements for guilt? The inquiry was not, and has never been whether the evidence was cogent, plausible or constituted proof of guilt beyond a reasonable doubt. The role of a judge in an English criminal court (of first instance) and the limitations on their functions were expressed thus: even if the judge considered that, because of inconsistencies, the evidence could not support a conviction, he should leave the matter to the jury; and the judge's obligation lies with cases where the necessary minimum evidence to establish the facts of the crime has not been called, and it is not his responsibility to weigh the evidence and stop the case if he thinks the witness is lying - which is the function of the jury. ${ }^{9}$

\subsection{Early Stages of Development}

In the South African context, the earliest interpretations of the procedure by the Appellate Division left very little space for judicial discretion when faced with an application for discharge at the close of the state's case. The position was that if there was no evidence of the accused's guilt on the charge or a competent charge, then the judge was required to discharge the accused from prosecution - removing his case from further consideration and thus rendering a verdict of not guilty. ${ }^{10}$

The Appellate Division's resolute approach appeared, however, to have waivered in 1919 and thereafter, when it adopted the position that judges had a discretion on whether to grant the application for discharge. ${ }^{11}$ The reason for the shift is unclear. ${ }^{12}$

Later, in 1925, the Appellate Division explained that the words "no evidence" do not mean "no evidence at all" - but rather "no evidence on which a reasonable court, acting carefully, might convict". ${ }^{13}$ This

$8 \quad$ Metropolitan Railway Co v Jackson (1877) 3 A.C 193 (HL) 197

$9 \quad R \vee$ Barker (1977) $65 \mathrm{Cr}$ App R 287, 288. See, also: $R v$ Galbraith (above) 1062 .

$10 \quad R v$ Louw 1918 AD 344; $R$ v Thielke 1918 AD 373.

$11 R v$ Lakatula 1919 AD 362, 364; R v Abrahamson 1920 AS 283, 285.

12 That is, it is not obviously political nor did it coincide with a drastic change to the bench at the time, nor did it follow legislative changes.

$13 R v$ Shein 1925 AD 6 (W). 
interpretation is perhaps the only aspect of the section 174 procedure that has remained stable and consistent in its application. ${ }^{14}$

\subsection{Judicial Discretion to Grant or Refuse an Application for Discharge}

Until the decision of the Supreme Court of Appeal (SCA) in S v Lubaxa, ${ }^{15}$ the judicial approach to the existence of a judicial discretion in deciding applications for discharge was unclear - with each court taking a different approach.

At the conservative end of the spectrum was the view that even where the state had failed to make out a case against a single accused person, a court had a discretion to refuse an application for discharge on the basis that the accused, if he testified, may lead evidence adverse to his cause. This was expressed in $S v$ Shuping, ${ }^{16}$ in which Hiemstra CJ rendered a judgment intended to provide guidance to the magistrates' courts when faced with section 174 applications. This he did by formulating a two-part test. First, he adopted the test formulated years earlier in $S v$ Shein, ${ }^{17}$ namely: Is there sufficient evidence upon which a reasonable person might convict? He then added a second leg to the test: Even if not, is there a reasonable possibility that the defence evidence might supplement the state's case? He referred to the second leg of the test as the 'discretionary component'. The court reasoned that this reasonable possibility could be inferred by the nature of cross-examination, a plea explanation, or from the existence of multiple accused persons. ${ }^{18}$

In applying his newly formulated test to the accused in Shuping, Hiemstra CJ found that the version of the state's key witness was uncorroborated by physical evidence which ought to have been available, and was further contradicted by other witnesses. He concluded that the evidence was insufficient for a reasonable person to convict all of the accused. Despite this finding, he also made use of part two of his test, and concluded that the application for discharge ought not to have been granted. To support this stance he said that where a case continued against one or more of several accused, it was unwise to discharge the others at that stage as they might be incriminated by those against whom the case continues - and it could appear that the discharge was premature and that there was a miscarriage of justice. ${ }^{19}$

Clearly, the new constitutional dispensation would affect South African criminal law and procedure, and it did so in respect of section

$14 R v$ Herholdt (3) 1956 (2) SA 722 (W); S v Mpeta 1983 (4) SA 262; S v Shuping 1983 (2) SA 119 (B); S v Phuravhatha 1992 (2) SACR 544 (V); S v Lubaxa 2001 (2) SACR 703 (SCA).

152001 (2) SACR 703 (SCA).

161983 (2) SA 119 (B).

17 Shein supra.

18 Shuping 148.

19 Shuping 148. 
174 applications. There have been several rights-based critiques of the Shuping test - more so in respect of the discretionary component.

At the vanguard was $S v$ Mathebula, ${ }^{20}$ decided under the interim Constitution, in which the High Court declared it would be grossly unfair after the prosecution had failed to prove any evidence against an accused, for the court not to acquit him on the possibility of future evidence being tendered by him or a co-accused. ${ }^{21}$ The case, however, involved the rare instance where there was no evidence against the accused, and must therefore be distinguished from cases where there is some evidence, or where the evidence is of a questionable quality. Essentially, Mathebula stressed that to afford a judge the discretion (contained in the second leg of the test in Shuping) in instances where the state does not adduce sufficient evidence upon which a reasonable person could reasonably convict, would be a violation of the right to be presumed innocent and the right against self-incrimination (including the right not to testify and to remain silent).

In $S v$ Lubaxa the SCA jettisoned the second part of the Shuping test from South African law. Although the court acknowledged the preexisting constitutional arguments against the Shuping test as set out in Mathebula above, it advanced different reasons for its conclusion. It maintained that to force a full trial in the hope that an accused would incriminate themselves where the state's evidence had failed to do so, was a violation of the right to dignity and personal freedom, which, according to the court, were already embodied in common law principles. The main principle in question is that there should be 'reasonable and probable' cause to believe that an accused is guilty of an offence - before initiating a prosecution. The court considered that the constitutional protection accorded to dignity and freedom appeared to underpin this position. Therefore, if a prosecution is not to commence without that minimum of evidence, it should cease when the evidence falls below the threshold. ${ }^{22}$

The rule which emerged from Lubaxa was that a single accused is entitled to be discharged at the close of the case for the prosecution, if there is no possibility of a conviction other than if he enters the witness box and incriminates himself. ${ }^{23}$ It would seem there was no longer a judicial discretion in such cases. The SCA was, however, explicit in stating that the removal of a judicial discretion (i.e. part two of the Shuping test) did not necessarily apply in cases involving multiple accused persons where an accused could be implicated by his co-

201997 (1) SACR $10(\mathrm{~W})$.

21 Mathebula 147.

22 Lubaxa para 19. In discussing the court's duty to discharge an unrepresented accused mero motu, it hinted at its inclination, referring to "the profound sense of injustice that is evoked by the spectacle of an accused bringing about his own conviction solely through his unfamiliarity with legal procedure" (para 17).

23 Lubaxa para 18 
accused. The court specifically indicated that it is important to distinguish between the state's case being supplemented by defence evidence in the form of an accused person incriminating himself, and where there are multiple accused and one is incriminated by his co-accused. ${ }^{24}$

The SCA therefore purposely left room for a modicum of judicial discretion in cases involving multiple accused - by stating that the issue of whether and in what circumstances a trial court should discharge an accused who might be incriminated by a co-accused, cannot be answered in the abstract. For a fair trial to ensue and the interests of justice to be served, this question should be determined on a case-bycase basis, with reference to the particular circumstances of each case. ${ }^{25}$

While the SCA was open to the need to assess the appropriate judicial response in each case involving multiple accused persons, it was resolute in laying down a blanket rule in cases relating to a single accused - and removed judicial discretion in every case involving a single accused. However, this may have been somewhat over-enthusiastic, for (to use the court's words) "one can envisage circumstances in which to [discharge an accused] would compromise the proper administration of justice". 66 One such circumstance was demonstrated in $R v$ Mall $^{27}$ where, although the accused stood trial alone, he was alleged to have acted together with accomplices $^{28}$ who did not stand trial with the accused but instead gave evidence against him. Because of the rule which requires corroboration of accomplice testimony by a non-accomplice, the only way the prosecution could elicit such corroboration was through the accused's own testimony. The court adopted the view that in instances where the only way for the state to make its case would be if an accused were to enter the witness stand and risk incriminating himself - then the accused should be discharged. The court therefore discharged the accused as he was the only person, other than the accomplices, who could corroborate their versions.

The Mall case - decided decades before Lubaxa - adopted an approach similar to that in Lubaxa. However, this approach is at odds with the balanced approach required in the pursuit of justice. Moreover, it could lead to the absurd result where each time a court is faced with an individual accused who committed an offence with one or more other people who have turned state witness/es, in instances where nobody else knew of their plan or of the offence that had been committed, then that individual accused can never be convicted unless he is tried with at least one of his accomplices. Based on these reasons, it is unfortunate that the SCA did not recognise that the need for judicial discretion could also arise in respect of a single accused person.

24 Lubaxa para 15.

25 Lubaxa paras 20-21.

26 Ibid.

271960 (2) All SA $403(\mathrm{~N})$.

28 Ibid at 407. See, also, $R$ v Herholdt (above) 273. 
It is unclear what the SCA would decide now if faced with a challenge to judicial discretion in cases involving multiple accused. The English position is favourable to an accused in this situation. It holds that an accused person is entitled, as of right, to a discharge if there is no evidence against him and, if this is refused him and he is later convicted as a consequence of evidence given by his co-accused, his appeal will succeed. ${ }^{29}$ Mathebula, discussed above, also supports this position - but only in instances where there is absolutely no evidence against the accused.

Despite the rule which emerged in Lubaxa it is often ignored that the SCA ultimately did not grant the application for discharge in that case. The court found that evidence of the commission of the crimes (robbery and murder under the doctrine of common purpose), and the arrival of Lubaxa with the other accused and their continued association until after the commission of the crime, constituted sufficient evidence upon which a reasonable court may convict (i.e. sufficient evidence for the state to avoid a discharge). As the court explained, "[I]f anything was lacking in the evidence at that stage it was an innocent explanation". 30

This statement appears to lie at the heart of the section 174 enquiry. This, together with an appreciation of the appropriate approach to the question of whether there is sufficient evidence upon which a reasonable person would convict, is what South African courts appear to be missing. Courts are failing to distinguish between spurious state cases in which there is actually no case to answer, and cases where the evidence presented proves the elements of the offence sufficiently for a reasonable person to convict on. It is submitted that it was the inability of the court to make this distinction in $S v$ Dewani, which led to a miscarriage of justice in that matter.

\subsection{The Question of Evidence at the Close of the State's Case}

It is trite law that the standard which the state evidence must meet at the close of its case, in order to avoid an accused being discharged, is lower than the standard that it must meet to secure the accused's conviction. ${ }^{31}$ For example, in $R v$ Louw $^{32}$ the Appellate Division rejected an argument by the defence that the accused should have been discharged at the close of the state's case, because "the evidence produced at the trial was so inconsistent with the innocence of the accused". 33 In dismissing this approach, the Court said that it does not follow that because in a certain view of the facts the evidence might suggest innocence, the accused must be acquitted, and that the jury may (and did) not take that view. ${ }^{34}$

$29 R$ v Abbot 1955 (2) AER 899 (CCA).

30 Lubaxa para 24

31 Lubaxa 2001 (2) SACR 703 (SCA).

32 R v Louw 1918 AD 344.

33 Louw 352.

34 Louw (above) 353. See also Thielke (above) 375, 379; Lakatula 365-366. 
This was also the case in $R v$ Shein, ${ }^{35}$ where the court found that existence of the following evidence on a count of arson was sufficient to refuse a discharge at the close of the state's case: (i) clear evidence that the fire was deliberate; and (ii) circumstantial evidence that the accused had committed the crime (including motive and presence at the property around the time the fire would have been set). The accused did present alternative versions, but suggested mistakes or inconsistencies in the eye-witness accounts of his presence, at the key times, on the property. The court was firm, however, and maintained that these were matters of assessment which involved the evaluation and weighing up of evidence. The imperfections in the state's evidence did not necessarily mean that there was no evidence upon which a reasonable person might convict. The court accordingly stated that the test was for an absence of evidence probative of the crime. ${ }^{36}$ In other words, the judge had to determine whether the facts necessary to sustain a particular charge or claim have been shown, and the jury was to determine whether those facts having been shown, were sufficient to warrant a conviction. ${ }^{37}$

Acknowledging the standard in theory, the courts however appear to have fallen short in practice. Even the court in Shuping ${ }^{38}$ would not have needed to devise a second leg to the discharge inquiry if it had taken the correct approach - that is, if it had confined itself to determining the existence of evidence upon which an accused might be convicted. In Shuping, there was evidence in the form of an eye-witness account which was not disqualified. That the witness was a single eye-witness, or given that there was no corroborating evidence, or that aspects of her testimony were contradicted by other eye-witnesses (as Hiemstra CJ noted $)^{39}$ - did not mean that there did not exist admissible evidence probative of the elements of theft.

The approach to evidence at the stage of an application for discharge was well articulated in $S v$ Cooper. ${ }^{40}$ The court stated it was the duty of the judge to determine the presence or absence of facts suitable to be considered by the jury, and, if such facts existed, then the jury had to evaluate the evidence in reaching a final decision in the matter. The court was explicit in stating it was neither the task nor the responsibility of the judge to evaluate the evidence. It should be noted that this is also the post-constitutional approach - as was illustrated in Lubaxa above.

The only exception to this rule in South African law is that a court may discharge an accused when the state's evidence is of such poor quality that no reasonable man acting carefully could convict thereon. ${ }^{41}$ This exception which permits a limited probe into credibility, appears to be a

35 Shein 10-11.

36 Ibid.

37 See Thielke (above) 375, 379.

38 Shuping 121.

39 Ibid.

40 [1974] 3 All SA 253 (T) 266.

41 Schwartz 2001 (1) SACR 334 (W). 
difficult line to tread - as courts have employed the concession to venture into detailed 'weighing up' exercises. It is submitted that this is neither within their remit nor competence at the stage of the close of the state's case.

\subsection{Recent Cases Which Confused the Issue}

The decision of the court in $S v$ Agliotti $^{42}$ warrants the conclusion that the court was confused about the limitations of the inquiry into credibility at the stage of the section 174 application - when it concluded that the state's key witness lacked credibility to such an extent that a discharge of the accused was merited. This conclusion and some of the court's other findings reached after it had engaged in a lengthy and inappropriate credibility analysis (and had seemingly capitulated to the defence's conjecture), are matters of concern when due regard is taken of the relatively low standard the state's evidence must meet in order to avoid discharge. ${ }^{43}$ In this case, the sole concern of the court in deciding if a discharge was justified, ought to have been whether there was sufficient evidence (the evidence taken at its highest) on which a reasonable court would convict. Had it made this restricted inquiry, it would likely have found that there was evidence, albeit inconsistent, that the accused had been part of a conspiracy to commit murder, and that the only aspect missing was an innocent explanation from him.

In $S \mathcal{V}$ Dewani, the Cape High Court considered a section 174 application by one of the accused. The accused had been charged with five counts of conspiracy, kidnapping, robbery with aggravating circumstances, murder, and obstructing the administration of justice. His alleged accomplices - far poorer than he and therefore accessing an entirely different level of legal representation - had entered into plea and sentence agreements. In order to sustain the charges against the accused who was alleged to have masterminded the criminal plan, the state had been required to prove that the accused had entered into a conspiracy

42 Sv Agliotti 2012 (1) SACR 559 (GSJ).

43 For instance, the court discussed the credibility of the witnesses in the following manner: "The startling similarities of the statements of Sanders, Nassif and others as well as the attribution of certain phrases to wrong people as well as the utilisation of incorrect dates and times indicates that there could have been collusion between them in the compilation of those statements. This impacts negatively on their credibility as witnesses and on the fairness of this trial. The timing of the supplementary affidavit by Nassif and its content which belatedly tend to implicate the accused herein point to a predetermined or premeditated course of action to implicate this accused in the crimes set out in the indictment. I cannot see any reason why, if the contents of this affidavit were true, they would not have been part of the section 204 statement that Nassif deposed to on 8 November 2006 or the statement he made on 10 November 2005. They sound to me to be recent fabrications and the defence's charge that they were specially invited or put to Nassif by the investigators or the prosecutors at the time for him only to glorify same with his signature may have a ring of truth to it." Agliotti paras 285-286. 
agreement with one of the alleged accomplices, Tongo. ${ }^{44}$ The court duly noted that "[i]t is common cause that the only witness who could implicate the accused was Tongo (who was an accomplice witness)". ${ }^{45}$ It consequently approached Tongo's evidence with caution, and required that it be corroborated. Certain CCTV footage existed which the state tendered in corroboration of Tongo's evidence of a meeting with the accused. Quite bizarrely, the court found that the CCTV footage did not meet the required standard for corroboration. This is a clear misdirection on the facts by the court, even on authority cited in the judgment:

"It must be emphasised immediately that by corroboration is meant other evidence which supports the evidence of the complainant, and which render the evidence of the accused less probable, on the issues in dispute" (original emphasis). ${ }^{46}$

Tongo had testified that he had met with the accused on specific occasions and that the accused asked him to arrange or commit the murder of his wife in exchange for money. The CCTV footage revealed that meetings took place between the two at the times and in the places alleged by Tongo. ${ }^{4}$ The CCTV footage could not of course confirm what was said during those meetings.

It is therefore unclear on what basis the CCTV footage failed to corroborate the accomplice's testimony. In addition, where an accused is known only by one person to have committed a crime, and where there is CCTV footage at least confirming the probability of the witness's version, the Court surely cannot be so circumspect in its approach to allow for the accused to avoid trial - merely because he managed to keep secret and guarded his involvement in a crime. The court was accordingly wrong to find that the CCTV footage did not corroborate Tongo's version, because the tape could not reveal "what was said during those events". ${ }^{48}$ It is submitted that that evidence equated to sufficient circumstantial evidence to warrant placing the accused on his defence. If, after his defence, the court was persuaded by the accused's explanation regarding his meeting with Tongo, the payment made to him, and the telephone calls placed by him - then it could discharge the accused. However, the testimony led by the state together with the objective supporting evidence tendered and the series of seemingly strange coincidences - cried out for an "innocent explanation" by the accused. To have discharged the accused under these circumstances amounted to a misdirection on the law which hamstrung the state.

The court was equally wrong to dismiss Tongo's evidence because of certain contradictions, mistakes and (in its view) inadequate

44 S v Dewani [2014] JOL 32655 (WCC) para 5.

45 Idem para 16. See, also para 23.1.

$46 S v$ Gentle cited in Dewani para 19

47 Dewani para 21.

48 The court found the same in respect of a telephone call which was proved to have taken place, though the content could not be revealed - as with the CCTV footage. 
explanations for the mistakes. In a clear misapplication of the law and a misjudgment of its role at the stage of discharge, the court had found that in Tongo's case, there were manifest material contradictions and inconsistencies in his evidence and several improbabilities, of sufficient degree as to render his evidence suspect. ${ }^{49}$ However, this ought not to have formed the basis on which to find that the evidence carried no weight to place the accused on his defence. This is compounded by the court stating at the end that "In making this finding to reject the witness evidence, I take into account that all three witnesses (...) are intelligent people, and therefore more than capable of attempting to twist their version to implicate the accused". ${ }^{2}$ To add insult to injury, the court even found that there were aspects of Tongo's evidence which implicate the accused. ${ }^{51}$ Surely this finding, followed by corroboration, was where the inquiry should have ended, as the application of the cautionary rule - which is a weighing up mechanism - had no place at this stage of the proceedings.

Although the court acknowledged the rule that evidence adduced by the state should only be ignored if it is of such poor quality that no reasonable person could accept it, it evidently failed to appreciate the nature of this requirement in its analysis at the close of the state's case. ${ }^{52}$ Had the court applied the test correctly, it would have found: (i) evidence existed in this case in the form of an accomplice whose evidence, taken at its highest, was not so far-fetched or inadequate that a reasonable person would not believe it; (ii) there was corroboration of this evidence in terms of the legal requirements; and (iii) the evidence tended to show a conspiracy agreement between the accused and Tongo. This is what the state needed to show, perhaps not for conviction - but to avoid discharge. Instead, the court tried the facts, and discharged the accused at the close of the state's case after having conducted an evaluation of the evidence. Courts, it is submitted, are not entitled to discharge an accused simply because the state's case is weak.

$49 S v$ Dewani para 23.1.105.

50 Dewani para 24.4.

51 Dewani para 23.1.107.

52 This is evident in the following statement of the court: "As pointed out above, Mr. Tongo is a single witness who is also an accomplice witness. As I have noted earlier, in these circumstances the court must look for corroboration of his evidence. On the cases referred to above it is clear that such corroboration must be corroboration implicating the accused. Mr. Mopp attempted to persuade me that I could find corroboration in the circumstantial evidence. This evidence, such as it is, he was constrained to concede does not implicate the accused. Regrettably, there are many unanswered questions about what exactly happened on the fateful night. (...) In the light of the analysis of the State case there is no evidence upon which a reasonable court, acting carefully, can convict the accused, and I am obliged to follow the established legal principles regarding a discharge. The law is clear: the evidence of the accused - if he does not incriminate himself can never strengthen the State's case. Even if the accused is therefore a wholly unsatisfactory witness - I will still be left with a weak State case which cannot on any basis pass legal muster." See: Dewani para 24.7. 
By contrast, the correct approach was displayed in Masondo $v S$, where Kgomo J decided an application for discharge in accordance with the prevailing international and local standards which the state must meet. In refusing to resort to probabilities, the judge said that:

\begin{abstract}
"The gist of the matter herein is that as opposed to situations where there is no evidence on record, in this case there is indeed evidence led against him which, if found to be cogent and credible, may amount to a prima facie case against him. I must make it clear that I am not saying the accused's guilt on these two counts have been proved beyond reasonable doubt. I am saying the evidence led, when juxtaposed to the forensic evidence and the evidence of pointing out which has already been accepted against accused 2 is such that it calls for reply." 53
\end{abstract}

There are clearly differing views of judicial power at this stage of a trial, or at least the full extent of the credibility inquiry which judges are required to undertake. A similar situation of differing judicial practices occurred in England, and was settled in $R v$ Galbraith. ${ }^{54}$ In this case the Criminal Court of Appeal (CCA) attempted to settle a dispute about whether the test for discharge was "no evidence" or whether a judge should stop the case if - in their view - it would be unsafe (alternatively unsafe or unsatisfactory) for the jury to convict. The court wisely noted that there were risks inherent in such wording which could lead to a deviation from the true purpose of the procedure and compromise the integrity of the jury system. It felt that a judge could hardly be blamed for evaluating the prosecution's evidence if he were to be obliged to consider whether a conviction would be 'unsafe' or 'unsatisfactory'. 55 The CCA therefore clarified the approach by refusing to grant a discharge - even where evidence and aspects of the record were favourable to the accused and possibly exculpatory, including internal inconsistencies in witness testimony and the inability of witnesses to identify the accused in identity parades. ${ }^{56}$ The court considered that the jury should be left to evaluate the weight on which the Crown had based its case. It found that Galbraith was not a case which could justify the judge stating that the Crown's evidence, at its best, was such that the jury, properly directed, could not convict on it. ${ }^{57}$

This attitude of the English criminal courts encompasses the very essence of what is being submitted - that the judge's role in assessing a section 174 application is not to assess credibility. This was most explicitly stated by Lord Devlin when he said:

"[T]here is in truth a fundamental difference between the question whether there is any evidence and the question whether there is enough evidence. I can best illustrate the difference by an analogy. Whether a rope will bear a certain weight and take a certain strain is a question that practical men often

53 Masondo (above) paras 43-44.

$54 R v$ Galbraith [1981] 1 WLR 1039.

55 Galbraith (above) 1062.

$56 \quad 1062-1063$.

571063. 
have to determine by using their judgment based on their experience. But they based their judgment on the assumption that the rope is what it seems to the eye to be and that it has no concealed defects. It is the business of the manufacturer of the rope to test it, strand by strand if necessary, before he sends it out to see that it has no flaw; that is a job for an expert. It is the business of the judge as the expert who has a mind trained to make examinations of the sort to test the chain of evidence for the weak links before he sends it out to the jury; in other words, it is for him to ascertain whether it has any reliable strength at all and then for the jury to determine how strong it is ..... 58

The Canadian decision of Perry $v$ The King, ${ }^{59}$ which still holds sway today, set the same standard. In Perry the court stated that the criterion to determine whether an accused should be put on his defence, is whether the evidence is such that, in the "absence of contradiction or explanation", "a jury might reasonably and properly convict upon". 60 The question of credibility is excluded to the extent that an accused may not be discharged if there is admissible evidence which could, if believed, result in a conviction. 61

Foreign jurisdictions therefore do not consider the credibility of witnesses at such an early stage, and applications for discharge are dealt with on the basis of whether the prosecution's evidence, if believed, would secure a conviction. It is submitted that, given the proven inability of judges to limit their credibility inquiry, this practice should be strictly emulated in South Africa, and the credibility assessment in section 174 applications should be abandoned. Currently, the credibility inquiry appears to be a uniquely South African problem.

\section{Current Relevance of Section 174}

The historical context for the discharge procedure no longer exists: The discharge procedure emerged at a time and as a result of jury trials, and where there lay no appeal against factual findings. ${ }^{62}$ In South Africa, the circumstances have since changed dramatically. Although an appeal on factual findings by the state is not permitted, a trial court's misdirection on facts is appealable. More significantly, the jury system was abolished some decades ago. ${ }^{63}$ However, this does not necessarily mean that the section 174 application procedure is now superfluous and without value. The question therefore is whether the procedure remains relevant under the current circumstances, and, if so, determining the optimal way in which it should be applied.

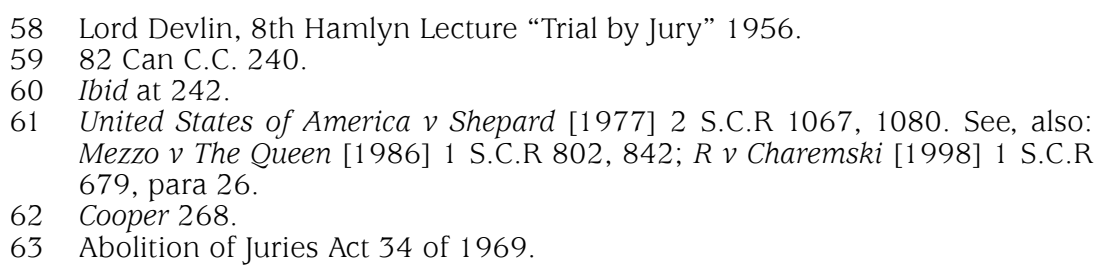


There are several aspects which require consideration when deciding if the discharge procedure still serves a purpose - despite the historical problems it sought to address no longer being in existence:

From an efficacy perspective, section 174 has practical usefulness in nipping problematic or frivolous prosecutions in the bud: it "cuts off the tail of a superfluous process". ${ }^{64}$ The drawbacks involved in having to resort to an appeal process in every instance of a frivolous prosecution are obvious. Therefore, it is preposterous for a person against whom there is no evidence, to be forced through an appeal process (including the time, expense and burden on the courts) in order to rectify so basic an error. Hence, section 174 provides for an exception to the normal trial procedure - primarily to relieve the trial court of the burden of mechanistically having to continue with a pointless trial when, evidently, a conviction will not be possible. As a result, a core function of section 174 is to "save time and effort, (and) not to complicate the court's task". 65

From a constitutional outlook, section 174 could be said to protect an accused against the risk of incriminating himself in instances where the state had not met the minimum standard it is required to meet for a prima facie case. Whether this right against self-incrimination should be regarded as inviolable is a separate question. Arguably, there are instances which would warrant the exercise of a judge's discretion in favour of the state. For example, where the state has adduced evidence against the accused in the form of satisfactory accomplice testimony, which need only be corroborated by a non-accomplice.

Furthermore, if the reasoning from Lubaxa were to be applied, the section 174 procedure is justifiable on the common law principle that there must be reasonable and probable cause to believe an accused is guilty, before initiating a prosecution. ${ }^{66}$ It can be argued that in the absence of a discharge procedure, an accused need only stand up and close his or her case without leading evidence. However, in dismissing this proposition as unrealistic, a sympathetic court in Lubaxa noted that it is "simplistic" to expect an accused person whose application for discharge was denied, to simply take the liberty gamble of closing his or her case without leading evidence, where he is of the view that the state has not met the standard required to show guilt. ${ }^{67}$ The court also considered that there are very few accused in this country qualified to

64 Masondo para 38.

65 Hiemstra's Criminal Procedure, 2008, 22.

66 See, also: Agliotti para 269, where the court refers to the purpose of the procedure in promoting orderly and fair criminal justice.

67 Lubaxa (above) para 16.

68 Ibid. The last sentence of this paragraph suggests that the court is equally sympathetic to represented and unrepresented accused. It is worth noting how differently represented and unrepresented accused experience the legal system, and the task of a person defending himself or herself is vastly different from a represented accused whose lawyer may well be up to the 
make such a decision - especially since most of them are unrepresented at their trials. ${ }^{68}$

The acknowledgement of how difficult it is to take the decision to close one's case without leading evidence, finds credence in the prevailing attitude that an accused's silence (even if as a result of poor judgment or advice) may in certain circumstances, to some extent be used against him when factual findings are being made. This arises from the nature of trial proceedings in an adversarial criminal justice system. Therefore, if the state has produced sufficient evidence to make out a prima facie case against an accused - such an accused would be at risk of conviction if they do not produce satisfactory evidence in rebuttal. A likely upshot is that, in the face of such circumstances, the accused may have to give up their right to remain silent. However, the fact that an accused has to make an election is not a breach of the right to silence, since if the right were to be so interpreted, this would sound the death knell of the very nature of an adversarial criminal justice system. ${ }^{69}$

For the above reasons it is submitted that the section 174 process still has value, and has taken on a life of its own. Consequently, there is no basis to believe that the absence of the historical factors which led to the process being created now renders the discharge process obsolete. On the contrary, the 'liberal' argument is more compelling, that, as there is now no distinction between judges and juries (specifically, that judges are now also the triers of fact) - it is appropriate to engage in an exhaustive or at least lengthy credibility analysis at the stage of a section 174 application, and to grant a discharge on the basis of a judge's finding that the state witness or witnesses are not to be believed.

Equally compelling, however, is the argument that the section 174 process has no regard for a victim's rights, and also the interest of the public in a full and fair trial being held.

\section{Victims in the Application of Section 174}

The court in Dewani impliedly came to the questionable (if not wholly unsubstantiated and condescending) conclusion that public and victim opinion was based on an emotionally overcharged hysteria, when it stated the following:

"I realise that there is a strong public opinion that the accused should be placed on his defence. I have taken note of that. I have also taken note of the plight of the Hindochas. I have however taken an oath of office to uphold the

task. Even in terms of represented accused, there is a vast difference between a wealthy accused and a concomitantly well-resourced legal team, and an accused being represented by over-burdened and under-resourced Legal Aid attorneys. Of course, to resolve this issue requires resolving structural inequality.

69 Osman v Attorney-General, Transvaal 1998 (4) SA 1224 (CC) para 22. See, also Boesak v S 2001 (1) SA 912 (CC) (para 24). 
rule of law and to administer justice without fear, favour or prejudice. That I cannot do if I permit public opinion to influence my application of the law. If any court permitted public opinion, which has no legal basis to influence their judgments, it will lead to anarchy. I am obliged to follow the established legal principles regarding a discharge at the close of the State case."70

Not every victim is emotional and unreasonable, and the public's interest in criminal trials should not be conflated with public opinion. Furthermore, the (modern) South African system of public prosecutions does not mean that the victim no longer has a role to play, or that the victim's interest should not be a consideration during the trial. The criminal justice process is strongly intertwined with victim and public interest, and is, regardless of preference, infused with social and economic considerations:

For instance, section $342 \mathrm{~A}$ of the Criminal Procedure Act ${ }^{71}$ contains a clear expression of the regard that must be had to the victim, in the court's decision on whether to discontinue a prosecution on the basis of an unreasonable delay in completing proceedings. The court is required to consider "the adverse effect on the interests of the public or the victims in the event of the prosecution being stopped or discontinued". 72

There has also been increasing cabinet recognition of the role of victims; the Service Charter for Victims of Crime in South Africa ("Victim's Charter) is a consequence of this recognition. The Victim's Charter is service-orientated, as the name suggests, and therefore does not include in its objectives and promises the sacrosanct area of judicial decision-making. It is not proposed that it do so. However, the Charter's objectives are useful in understanding the recognised interests of victims in the criminal justice process. The objectives are to: eliminate secondary victimisation in the criminal justice process; ensure that victims remain central to the criminal justice process; clarify the service standards that can be expected by and are to be accorded to victims whenever they come into contact with the criminal justice system; and make provision for victim's recourse when these standards are not met. ${ }^{73}$

A victim and the public generally have an interest in a conviction where an accused is guilty. They also have an interest in a full trial where the prosecution has presented a case for the accused to answer. Likewise, they also have an interest in the protection of an accused person's rights. However, these interests must be balanced, and not one forsaken for the other. Should that happen, there is a risk of victim/public dissatisfaction with the process.

70 Dewani 83.

7151 of 1977.

72 Section $342 \mathrm{~A}(2)(\mathrm{h})$ of the CPA.

73 Victim's Charter at 5. 
The public prosecution system on which the victims of crime and the public rely cannot be discussed in the abstract without noting its dire state, ${ }^{74}$ and without contrasting it to the legal teams to which wealthy accused persons have access. Victims in cases involving wealthy accused are often faced with the might of well-resourced, round-the-clock legal teams, while they have no option but to rely only on oversubscribed and underfunded public prosecutors.

The suggestion is not that the victim's interests be taken into account for the purposes of assessing guilt or innocence, or even at the stage of an appeal against a conviction. ${ }^{75}$ Nor is the suggestion that the victim's rights should trump the entrenched constitutional rights of an accused. However, the disregard of a victim's interest in a full trial and the reduction of public interest to mere opinion, without further substantiation, does not do justice to the full scope of the criminal justice system. Therefore, the proposal is that the victim's interests should be weighed up in the section 174 inquiry.

The complete disregard of the victim in the current judicial approach to the section 174 inquiry does not accord with the general appreciation for the role of victims in the entire criminal justice process. Seemingly, this has happened as a result of the expansion of the credibility inquiry coupled with the constitutional emphasis on an accused person's rights, and the historically entrenched idea of the state as dominus litus. It is submitted that these aspects have subverted the judicial approach in a most inappropriate fashion - one of imbalance between rights with the consequential risk of the public in general and victims specifically feeling that their interests are not protected.

\section{Conclusion}

The ability of wealthy accused to bankroll criminal litigation over an extended period gives rise to infinite possibilities for exploiting any legal loopholes and procedural mechanisms, and also for employing delaying tactics. As a result, this has become deeply prejudicial to victims and the public interest in the equal administration of justice. A jurisprudence which treats all litigants as equal before the law, ought to be developed to guard against this.

The section 174 process is not harmful in and of itself. However, its implementation presently has been harmful. Therefore, there needs to be an assessment of ways to make section 174 the device that it once

74 Mistry, D "Victims and the criminal justice system in South Africa" (1997), Paper presented at Centre for the Study of Violence and Reconciliation, Seminar No. 11, 29 October 1997.

75 See Morris v Slappy, 461 U.S. 1 (1983); United States $v$ Hasting, 461 U.S. 499 (1983), where the United States Supreme Court refused to uphold appeals against convictions, citing as a relevant factor in the inquiry the interests of the victims who testified at the initial trial. 
was - a sentinel against convictions in the face of spurious state evidence. The harm being experienced by victims of crime, public interest and the integrity of the criminal justice system, is the result of judges acting inappropriately at the stage of the section 174 application for discharge - as triers of fact. It is submitted that this is the source of the harm, and not the section 174 procedure itself.

In South Africa, occasional applications of the test for discharge have seen judges tending towards granting an application for discharge where they think that the witnesses for the prosecution are unreliable or are not telling the truth. This is incorrect and inappropriate. However, on the reasoning in Galbraith, a judge can hardly be blamed if he is asked or permitted to rule on credibility, if he were to grant a discharge based on such a finding. The credibility inquiry must therefore be abandoned.

Intensive credibility inquiries are never appropriate at the stage of the discharge application. The Dewani outcome clearly demonstrated as much. The reasons for this are twofold: (i) In terms of the section 174 procedure and its limitations as expressed in Lubaxa, a judge is simply not entitled to engage in such an inquiry at this stage of the trial; and (ii) this approach, even if the statutory provision were to develop to this extent, fails to adequately balance the interests of the victim in the criminal proceedings and the public interest in a trial.

To obviate this, it is submitted that as is the practice in foreign jurisdictions, when dealing with section 174 applications, judges in South Africa should take the state evidence "at its highest". The requirement that the state evidence be taken at its highest, will provide the necessary limited space for a court to discard completely unbelievable witness testimony. This procedure of abandoning the credibility inquiry can be adapted to non-jury settings. In The King $v$ Morabito $^{76}$ the Supreme Court of Canada considered an appeal concerning, among other things, an application for discharge in the case of a court sitting without a jury. Although the judge would ultimately be empowered to act as trier of fact, the court held that at the close of the state's case, he did not yet have that power. According to the court, the judge was still empowered only to decide whether there was evidence upon which a jury might convict and that he had no additional power at that stage by virtue of sitting without a jury. ${ }^{77}$ The court went on to state:

"Had a jury been present, the learned trial judge could have done no more, on the application of the defence, than have decided whether or not there was evidence upon which a jury might convict ... [The judge] would have had no right, as he in fact did, to proceed to weigh the evidence until all the evidence was in. The decisions are uniform." 78

76 The King $v$ Morabito [1949] S.C.R.172.

77 Morabito 174.

78 Morabito 175. 
What does this mean for the application of the discharge procedure in an era without juries? The answer is simple: The judge must ask himself whether there is any evidence on which to base a charge. He must reserve the weighing up or assessment of that evidence for when the trial has closed. If he does not perform that exercise, and splits his functions at the close of the state's case and at the end of the trial as a whole - then he places the state in a position where it is required to meet an unduly high, if not impossible, burden without the other side testifying.

In other words, the judge needs to delineate and understand his role at the two key stages of the trial: (i) at the close of the state's case he is to draw a legal conclusion on the existence of evidence required for a particular offence; and (ii) at the close of the trial as a whole he is to draw his factual conclusions from the existing evidence. ${ }^{79}$

Based on the existing legal standard, then, a legislative leap is unnecessary. What is necessary, however, is an appreciation by judges of their shifting functions at different stages of a criminal trial.

79 This distinction in the judge's function has been expressed in some way in $S v$ Cooper [1974] 3 All SA 253 (T) 266 at 890: "If there is more than one inference possible from the facts assumed to be uncontradicted at the close of the case for the prosecution, then that is just the sort of evidence that should be referred to the triers of fact for decision." 